\title{
ANALISIS BIBLIOMETRIK MUSLIM TRAVEL: PUBLIKASI ILMIAH DI NEGARA-NEGARA SELURUH DUNIA
}

\author{
Mochammad Givary Ramadhan \\ Universitas Muhammadiyah Sidoarjo \\ Email: givaryvicky99@gmail.com \\ M. Ruslianor Maika \\ Universitas Muhammadiyah Sidoarjo \\ Email: mr.maika@umsida.ac.id
}

\begin{abstract}
This study aims to determine the development map of research related to "Muslim Travel". This research was conducted by searching through the Scopus database. The researcher uses the keyword "Muslim Travel" to generate searches to be more specific with the categories Article title, Abstract, Keywords. In this study, the researcher used a quantitative descriptive method with bibliometric analysis. Based on the search results, the researchers obtained 649 scientific work search results which were then limited to using only two types of article documents and conference papers and then produced 416 documents which were then exported in BibTex format and processed using R-Packages and WebInterface Biblioshiny software, In this study featuring Thematic Maps, on Thematic Maps researchers found that the keyword that appeared most associated with Muslim travel was Human followed by Female.
\end{abstract}

Keywords: Muslim Travel, Biblioshiny, Scopus.

\section{Pendahuluan}

Pengetahuan dan kesadaran akan pentingnya suatu produk halal menjadikan pertumbuhan pada sektor industri halal semakin meningkat(Ayatina, Astuti, and miqdam Makfi 2020). Meningkatnya pertumbuhan sektor industri halal tersebut berakibat pada munculnya pariwisata muslim (Muslim Travel) di berbagai penjuru dunia(Samori, Md Salleh, and Khalid 2016). Begitu pula dapat dilihat dengan kemajuan industri pariwisata halal, banyak negara di dunia berusaha menangkap pasar wisatawan muslim dengan menyediakan produk pariwisata, sarana dan 
prasarana yang memenuhi kebutuhan mereka(Kusumaningtyas et al. 2021). Hal tersebut juga dapat dilihat dari pertumbuhan publikasi ilmiah yang berkaitan dengan "Muslim Travel" atau perjalanan muslim. Peningkatan industri pariwisata dan perjalanan muslim dipelopori karena terdapat banyak permintaan pasar yang menyebabkan terciptanya sebuah daya saing yang benar - benar kuat di dunia internasional(Shofi'unnafi 2020). Oleh sebab itu memang tidak sedikit terjadi pada negara seperti Indonesia, Jepang, Malaysia dan negara - negara lainnya(Arifiyyati 2020). Baik pariwisata maupun perjalanan muslim dimaknai sebagai sebuah destinasi wisata yang dapat dijadikan sebagai pilihan, menurut perspektif syariah karena dalam suasana perjalanan maupun pariwisata muslim ini dilakukan sebagai upaya untuk menghindari pencemaran terhadap hal - hal yang diharamkan(Rusydiana, Muhammad, Pratomo, Endang 2021).

Adapun kajian yang berkaitan dengan penelitian pariwisata dan perjalanan muslim "Muslim Travel" dapat dilakukan lebih banyak dan dapat di riset lebih luas dan lebih mendalam(Prasetyo 2021). apalagi publikasi ilmiah terkait pariwisata dan perjalanan muslim dapat menjadi sebuah evaluasi, rujukan dan pengembangan di masa yang akan datang, oleh sebaboleh karena hal tersebut peneliti melakukan analisa bibliometrik guna mengetahui secara kuantitatif melalui publikasi - publikasi ilmiah yang di publikasikan adapun yang berkaitan dengan pariwisata dan perjalanan muslim khususnya hal - hal yang lebih membahas mengenai "Muslim Travel".

Pada awalnya analisa bibliometrik di kenalkan oleh Nalimov, Pritchard dan Mulchencko ditahun 1969. Pritchard menjelaskan bibliometrik adalah sebuah metode yang menggunakan baik matematika maupun statistik terhadap buku dan media media komunikasi lainnya(Tupan et al. 2018). Adapun analisis bibliometrik merupakan metode yang akurat dan objektif untuk mengukur dan menghitung sebuah kontribusi artikel bagi kemajuan pengetahuan(Hayati and Lolytasari 2017). 
Bibliometrik juga merupakan sebuah metode yang sering digunakan untuk menganalisis tren dan kinerja pada subjek tertentu(Herdianto et al. 2021). dan Analisis bibliometrik juga merupakan sebuah metode yang dipakai dalam menganalisa sebuah data bibliografi yang didapatkan dari berbagai literatur(Sidiq 2019).

Oleh sebab tersebut, penelitian ini dilakukan guna melihat dan mengukur sebuah perkembangan serta produktivitas sebuah publikasi dari hasil penelitian dalam berbagai aspek seperti kata kunci, kolaborasi penulis pada data yang didapatkan dari publikasi ilmiah yang memuat kata kunci "Muslim Travel" selanjutnya diolah menggunakan perangkat lunak R-Packages dan WebInterface Biblioshiny. Hasil penelitian ini diharapkan dapat memberikan nilai kebaruan (novelty) dalam penelitian bidang perjalanan dan pariwisata terutama perjalanan (Travel) dan pariwisata (Tourism) muslim untuk memberikan gambaran perkembangan karya ilmiah yang ada di seluruh dunia.

Beberapa penelitian yang kami temukan belum menggunakan Biblioshiny dalam memetakan karya ilmiah perjalanan dan pariwisata muslim di seluruh dunia. Adapun penelitian bibliometrik pada bidang perjalanan dan pariwisata muslim, setidaknya peneliti menemukan tiga penelitian terbaru. Penelitian Pertama dilakukan oleh Hendi P (2021) melakukan studi mengenai Analisis Bibliometrik Pada Scholarly Journals Proquest Dengan Kata Kunci "Tourism In Indonesia" Menggunakan Perangkat Lunak Vosviewer, data yang digunakan didapat dari ProQuest dengan menggunakan kata kunci "Pariwisata di Indonesia" dan menemukan sebanyak 56 artikel, peneliti mengambil data dari tahun 1993 sampai dengan tahun 2020 dari hasi penelitian yang telah di lakukan menampilkan bahwa artikel terbanyak termuat tahun 2019 berjumlah 11 (20\%) artikel terbitan dan terbitan terbanyak kedua terdapat pada tahun 2016 sebanyak 9 (16\%) artikel terbitan.

Penelitian kedua dilakukan oleh Khaeril, Mahlia, Jusni \& Muis (2020) melakukan studi tentang "Daya Saing Tujuan Wisata: Kajian Pustaka Sistematis" 
dengan menggunakan analisis bibliometric, data yang digunakan dalam penelitian di dapatkan dari Google Scholar lalu oleh peneliti data diolah dengan perangkat lunak Publish or Perish dan di visualisasikan menggunakan Vosviewer. Artikel yang menjadi rujukan pertama peneliti dalam kurun waktu 2005 - 2020 dan terdapat sebanyak 100 artikel terbitan. Dari data yang di gunakan peneliti menemukan 880 sitasi pada data tersebut.

Penelitian ketiga dilakukan oleh Aam, Muhammad, Wahyu, Endang \& Yulizar (2021) melakukan sebuah studi mengenai "Indikator Wisata Halal: Studi Bibliometrik", berdasarkan penelitian yang telah dilakukan. Data berupa tahun terbit, kutipan dan penulis di analisa menggunakan perangkat lunak Microsoft Excel 2010. Selanjutnya tren perkembangan publikasi bidang pariwisata halal, kata kunci, penulis dan jurnal dianalisis menggunakan VOSViewer. Menghasilkan bahwa pertumbuhan publikasi ilmiah wisata halal dari tahun 2009-2020 mengalami peningkatan yang fluktuatif dan paling banyak diterbitkan tahun 2020 dengan jumlah 15 dokumen (23\%). Berikutnya Penulis yang paling banyak mempublikasikan hasil penelitian bidang wisata halal adalah Amr Al-Ansi. , Mohamed Battour dan Joan C. Henderson. Selain itu, jurnal pariwisata halal yang paling signifikan adalah International Journal of Tourism Research. Peneliti juga menemukan peringkat pertama dengan 372 sitasi adalah artikel dengan judul "Islamic Tourism and Managing Tourism: Development in Islamic Societies: The Cases of Iran and Saudi Arabia" yang ditulis oleh Zamanifarahani \& Enderson (2010).

\section{Metode}

Penelitian yang dilakukan oleh peneliti menggunakan metode kuantitatif. Sedangkan untuk Analisa menggunakan analisa bibliometrik dengan mengumpulkan hasil literatur yang didapatkan melalui database scopus dengan kata kunci "Muslim Travel". Penelitian ini menggunakan aplikasi Program R untuk mengolah dan memvisualisasikan data yang di dapat dalam database scopus. Populasi penelitian 
adalah publikasi ilmiah travel muslim di negara-negara seluruh dunia yang terindeks scopus selama periode 58 tahun (1963-2021). Jumlah populasi yang dimaksud adalah terdapat sebanyak 416 judul publikasi ilmiah. Pengumpulan data dengan melakukan penelusuran dan pencarian melalui database scopus dengan kata kunci Muslim Travel dengan katagori Judul Artikel, Abstrak, Kata Kunci dalam kurun waktu 1963-2021. Dan di batasi dengan menggunakan dua tipe dokumen: artikel dan conference paper. Data berupa ekstensi file BibTex yang dianalisa menggunakan WebInterface Biblioshiny, ada dua jenis Analisa yang pertama Analisa dan plot untuk tiga metrik tingkat yang berbeda: sumber dokumen, penulis, dan document artikel dan Analisa yang kedua adalah analisis tiga struktur pengetahuan yang pertama struktur konseptual, struktur intelektual dan struktur sosial.

\section{Hasil dan Pembahasan}

\section{Informasi Utama}

Pada bagian ini dibahas pertumbuhan publikasi ilmiah travel muslim di negara- negara yang berada di seluruh DUNIA berdasarkan tahun, jurnal inti dalam publikasi ilmiah travel muslim, jumlah publikasi ilmiah travel muslim berdasarkan lembaga/afiliasi, jumlah publikasi ilmiah travel muslim berdasarkan negara, jumlah publikasi ilmiah travel muslim berdasarkan subjek dan tipe dokumen. Tahun yang digunakan untuk menampilkan data publikasi ilmiah berkisar tahun 1963 - 2021, Terdapat dua tipe dokumen yang digunakan untuk menampilkan data publikasi ilmiah mengenai travel muslim yaitu: artikel dan conference paper, tipe dokumen artikel terdapat 398 dokumen dan tipe dokumen conference paper terdapat 18 dokumen.

Dalam data yang terdapat di publikasi ilmiah travel muslim terdapat tahun rata - rata dari publikasi sebesar 6.88, kutipan rata - rata per dokumen 9.966, kutipan rata - rata per tahun per dokumen sebesar 1.159 dengan referensi sebanyak 18698. 
Dan terdapat 951 penulis dari 416 dokumen publikasi ilmiah mengenai Muslim Travel, 193 penulis dokumen dengan satu penulis, 758 penulis dokumen dengan multi penulis, dan didapatkan 205 dokumen dengan penulis tunggal dari 416 dokumen Muslim Travel di dunia, 0,437 dokumen per penulis, 2.29 penulis per dokumen.

Tabel 1. Informasi Utama

\begin{tabular}{ll}
\hline Keterangan & Hasil \\
\hline INFORMASI UTAMA TENTANG DATA & \\
Rentang Waktu & $1963: 2021$ \\
Sumber (Jurnal, Buku, dll) & 307 \\
Dokumen & 416 \\
Rata-Rata Tahun Dari Publikasi & 6.88 \\
Kutipan Rata-Rata Per Dokumen & 9.966 \\
Kutipan Rata-Rata Per Tahun Per Dokumen & 1.159 \\
Referensi & 18698 \\
JENIS DOKUMEN & \\
Artikel & 398 \\
Conference Paper & 18 \\
ISI DOKUMEN & \\
Keywords Plus (ID) & 1683 \\
Author's Keywords (DE) & 1262 \\
PENULIS & \\
Penulis & 951 \\
Author Appearances & 1073 \\
Dokumen Oleh Penulis Tunggal & 193 \\
Dokumen Oleh Multi-Penulis & 758 \\
KOLABORASI PENULIS & \\
Dokumen Yang Ditulis Tunggal & 205 \\
Dokumen per Penulis & 0.437 \\
Penulis per Dokumen & 2.29 \\
Rekan Penulis per Dokumen & 2.58 \\
Indeks Kolaborasi & 3.59 \\
\hline
\end{tabular}




\section{Penulis Paling Relevan}

Grafik 1 membahas mengenai penulis paling relevan. peneliti mengambil 20 penulis paling relevan, pada peringkat pertama di tempati dengan perolehan 14 artikel dengan penulis Memish ZA, terdapat 2 penulis dengan perolehan 6 artikel dengan penulis Booy R dan Rashid H, 4 penulis dengan perolehan 5 artikel, 5 penulis dengan perolehan 4 artikel, dan 8 penulis dengan perolehan 3 artikel.

Tabel 2 membahas mengenai artikel difraknisasi pada 20 penulis yang paling relevan dengan perolehan total keseluruhan terdapat 27,41 artikel difraknisasi, perolehan artikel difraknisasi tertinggi oleh penulis Memish ZA dengan 5,33 artikel difraknisasi dan perolehan artikel difraknisasi terendah oleh Parola P dengan 0,44 artikel difraknisasi.

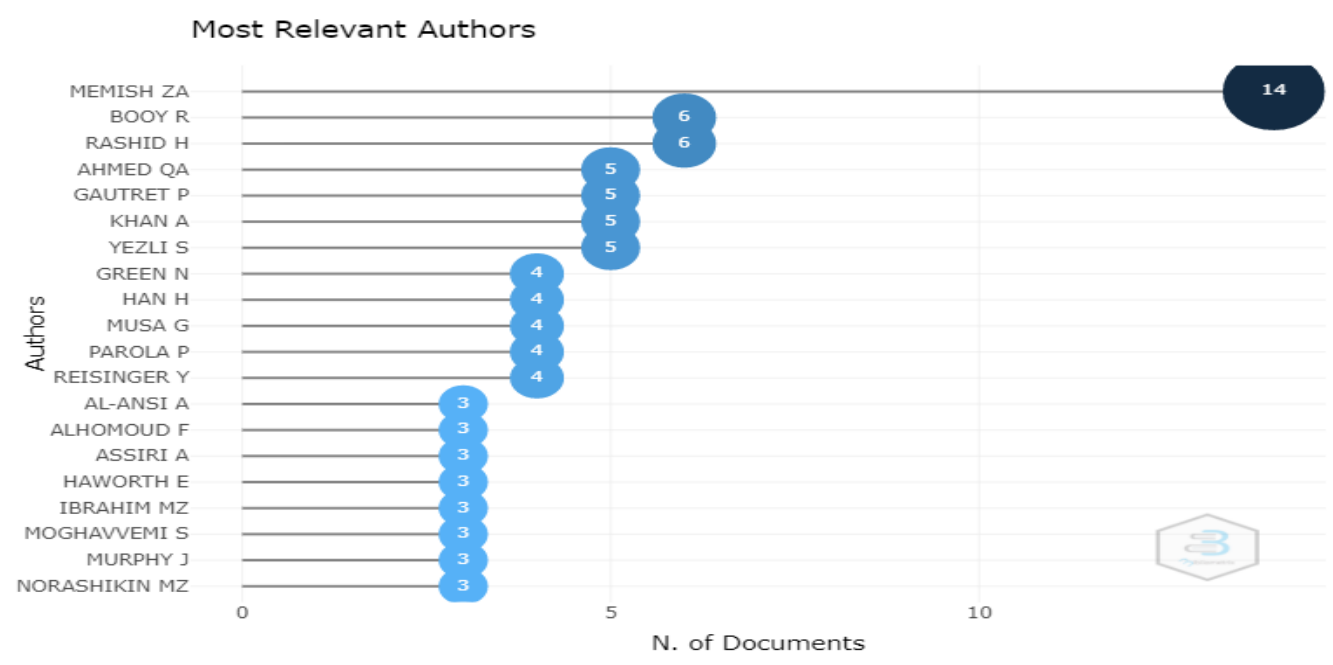

Gambar 1. Penulis Paling Relevan 
Tabel 2. Penulis Paling Relevan

\begin{tabular}{lcc}
\hline Penulis & Artikel & Articles Fractionalized \\
\hline MEMISH ZA & 14 & 5.33 \\
BOOY R & 6 & 0.97 \\
RASHID H & 6 & 0.95 \\
AHMED QA & 5 & 1.60 \\
GAUTRET P & 5 & 0.94 \\
KHAN A & 5 & 0.82 \\
YEZLI S & 5 & 0.87 \\
GREEN N & 4 & 4.00 \\
HAN H & 4 & 0.74 \\
MUSA G & 4 & 1.42 \\
PAROLA P & 4 & 0.44 \\
REISINGER Y & 4 & 1.50 \\
AL-ANSI A & 3 & 0.54 \\
ALHOMOUD F & 3 & 1.25 \\
ASSIRI A & 3 & 0.46 \\
HAWORTH E & 3 & 0.50 \\
IBRAHIM MZ & 3 & 1.50 \\
MOGHAVVEMI S & 3 & 1.25 \\
MURPHY J & 3 & 0.83 \\
NORASHIKIN MZ & 3 & 1.50 \\
\hline
\end{tabular}

Tabel 3 menampilkan jumlah penulis per dokumen. 280 (67,3\%) dokumen ditulis oleh penulis tunggal, dokumen sisanya $(136 ; 32,7 \%)$ ditulis oleh Multi penulis.

Tabel 3. Jumlah Penulis Per Dokumen

\begin{tabular}{llll}
\hline Jumlah Penulis & Frekuensi & $\mathbf{\% ( N = 4 1 6 )}$ & Total Kontribusi \\
\hline 1 & 280 & $67.3 \%$ & 280 \\
2 & 83 & $20.0 \%$ & 166 \\
3 & 35 & $8.4 \%$ & 105 \\
4 & 10 & $2.4 \%$ & 40 \\
5 & 4 & $1.0 \%$ & 20 \\
6 & 3 & $0.7 \%$ & 18 \\
12 & 1 & $0.2 \%$ & 12 \\
Total & 416 & $100.0 \%$ & 641 \\
\hline
\end{tabular}




\section{Produksi Ilmiah Negara}

Total keseluruhan terdapat 64 negara yang berkontribusi terhadap publikasi ilmiah mengenai Muslim Travel, berdasarkan perolehan data peneliti menemukan bahwa Negara USA menempati urutan pertama dengan perolehan 133 frekuensi kontribusi publikasi ilmiah Muslim Travel, dan selanjutnya diikuti oleh Negara Malaysia dan Saudi Arabia dengan perolehan 93 frekuensi, Indonesia dengan perolehan 35 frekuensi.

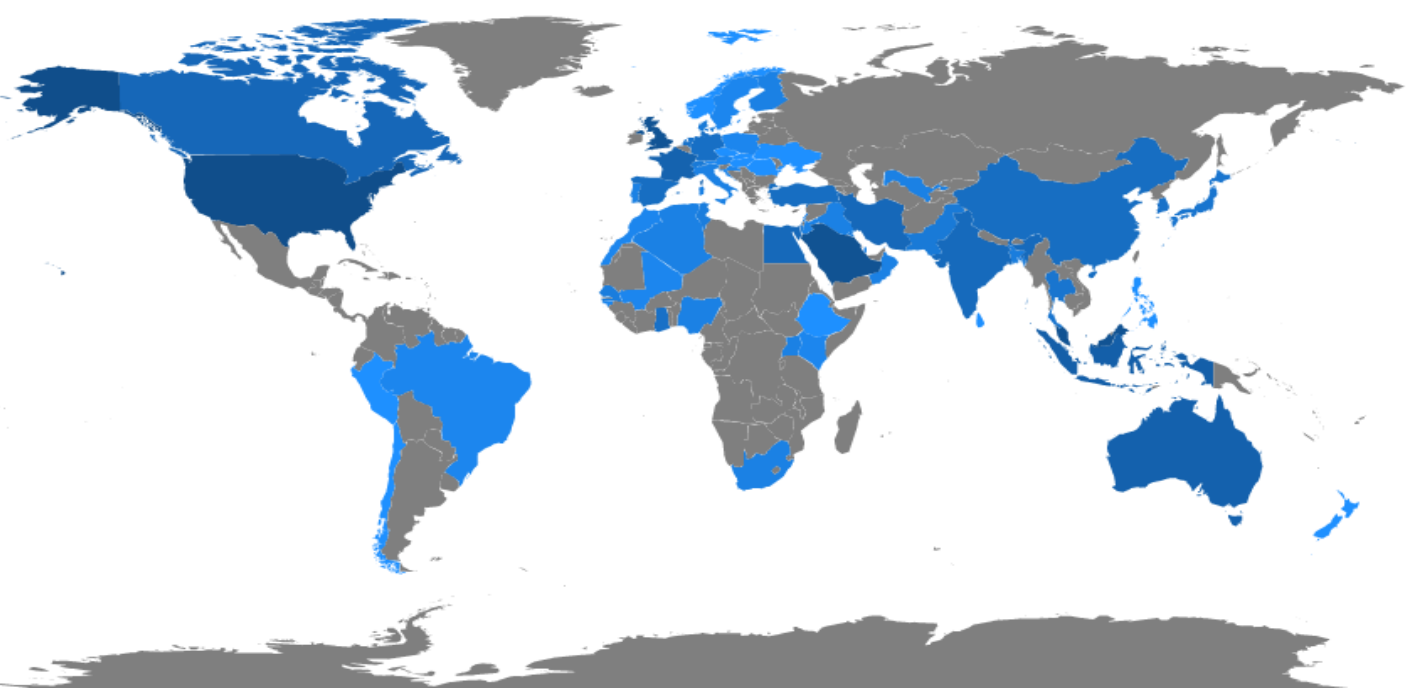

$\begin{array}{llllllll}\text { USA } & 133 & \text { GHANA } & 10 & \text { ITALY } & 3 & \text { MOROCCO } & 2 \\ \text { MALAYSIA } & 93 & \text { SOUTH KOREA } & 9 & \text { JORDAN } & 3 & \text { POLAND } & 2 \\ \text { SAUDI ARABIA } & 93 & \text { NETHERLANDS } & 8 & \text { NIGERIA } & 3 & \text { SWEDEN } & 2 \\ \text { UK } & 86 & \text { ISRAEL } & 7 & \text { OMAN } & 3 & \text { CHILE } & 1 \\ \text { INDONESIA } & 35 & \text { JAPAN } & 7 & \text { PORTUGAL } & 3 & \text { REPUBLIC } & 1 \\ \text { AUSTRALIA } & 30 & \text { THAILAND } & 7 & \text { QATAR } & 3 & \text { ETHIOPIA } & 1 \\ \text { FRANCE } & 27 & \text { DENMARK } & 5 & \text { SOUTH AFRICA } & 3 & \text { HUNGARY } & 1 \\ \text { CANADA } & 19 & \text { PAKISTAN } & 5 & \text { UGANDA } & 3 & \text { MALDIVES } & 1 \\ \text { IRAN } & 18 & \text { SWITZERLAND } & 5 & \text { UZBEKISTAN } & 3 & \text { NEW ZEALAND } & 1 \\ \text { EGYPT } & 17 & \text { BANGLADESH } & 4 & \text { AUSTRIA } & 2 & \text { NORWAY } & 1 \\ \text { INDIA } & 16 & \text { KUWAIT } & 4 & \text { BRAZIL } & 2 & \text { PERU } & 1 \\ \text { CHINA } & 12 & \text { SENEGAL } & 4 & \text { CROATIA } & 2 & \text { PHILIPPINES } & 1 \\ \text { SPAIN } & 12 & \text { TUNISIA } & 4 & \text { GUINEA-BISSAU } & 2 & \text { ROMANIA } & 1 \\ \text { TURKEY } & 12 & \text { ALGERIA } & 3 & \text { KENYA } & 2 & \text { SLOVAKIA } & 1 \\ \text { GERMANY } & 11 & \text { FINLAND } & 3 & \text { LEBANON } & 2 & \text { SRI LANKA } & 1 \\ \text { SINGAPORE } & 11 & \text { IRAQ } & 3 & \text { MALI } & 2 & \text { UKRAINE } & 1\end{array}$




\section{Jenis Dokumen}

Peneliti juga menganalisis dokumen yang telah dikumpulkan dari database scopus berdasarkan jenis dokumen, jenis sumber, serta judul sumber, jenis dokumen dapat berupa artikel jurnal, makalah referensi, review, artikel, buku, dan bab buku namun pada penelitian kali ini peneliti hanya menggunakan dua jenis dokumen yaitu artikel dan conference paper. Grafik dibawah ini menyajikan bagan Analisa jenis dokumen dari penelitian ini. Artikel mewakili lebih dari setengah, di ikuti oleh conference paper.

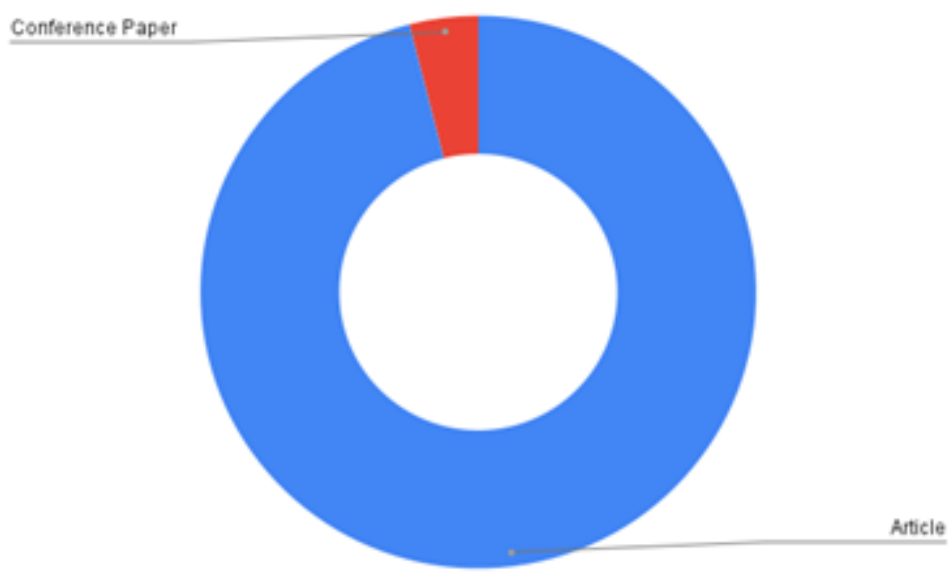

Gambar 2. Jenis Dokumen

Meskipun ada berbagai jenis dokumen untuk artikel yang membahas mengenai Muslim Travel namun peneliti hanya menggunakan artikel dan conference paper. Tabel 4 menunjukkan bahwa sebagian besar diterbitkan dengan tipe dokumen berupa artikel (96\%), diikuti dengan conference paper (4\%).

Tabel 4. Jenis Dokumen

\begin{tabular}{lll}
\hline Tipe Dokumen & Frekuensi & Persentase (N=416) \\
\hline Article & 398 & $96 \%$ \\
Conference Paper & 18 & $4 \%$ \\
\hline Total & 416 & $\mathbf{1 0 0 \%}$ \\
\hline
\end{tabular}




\section{Judul Sumber}

Studi mengenai Muslim Travel juga di terbitkan diberbagai artikel dan conference paper. Tabel 5 menampilkan judul sumber teratas bahwa topik mengenai Muslim Travel telah diterbitkan berdasarkan jumlah minimal 3 publikasi yang dihasilkan oleh setiap judul sumber dapat dilihat pada tabel 5 bahwa Journal of Islamic Marketing menjadi urutan tertinggi dalam Muslim Travel.

Tabel 5. Judul Sumber Teratas

\begin{tabular}{lll}
\hline Judul Sumber & Jumlah Terbit & \% \\
\hline Journal Of Islamic Marketing & 19 & $4.6 \%$ \\
Travel Medicine And Infectious Disease & 13 & $3.1 \%$ \\
Journal Of Travel Medicine & 6 & $1.4 \%$ \\
International Journal Of Environmental Research And & 5 & $1.2 \%$ \\
Public Health & 5 & $1.2 \%$ \\
Modern Asian Studies & 5 & $1.2 \%$ \\
Saudi Medical Journal & 4 & $1.0 \%$ \\
Tourism Management Perspectives & 4 & $1.0 \%$ \\
International Journal Of Culture Tourism & 4 & $1.0 \%$ \\
Hospitality Research & 4 & $1.0 \%$ \\
International Journal Of Infectious Diseases & 4 & $1.0 \%$ \\
Religions & 4 & $1.0 \%$ \\
South Asia Journal Of South Asia Studies & 4 & $0.7 \%$ \\
Tourism Management & 4 & \\
Bridging Tourism Theory And Practice & 3 & \\
\hline
\end{tabular}

\section{Bahasa Dokumen}

Bahasa yang digunakan dalam publikasi baik artikel dan conference paper mengenai Muslim Travel terdapat 12 bahasa dengan peringkat pertama bahasa Inggris dengan jumlah publikasi sebanyak 300 dengan persentase (72.1\%), diikuti bahasa Rusia (10.8\%), bahasa Perancis (7.2\%), bahasa Turki (4.8\%), bahasa Spanyol (2.2\%). 
Tabel 6. Bahasa Yang Di Gunakan Untuk Publikasi

\begin{tabular}{lll}
\hline Bahasa & Jumlah Artikel yang di Publikasikan & $\mathbf{\%}(\mathbf{N}=\mathbf{4 1 6})$ \\
\hline Inggris & 300 & $72.1 \%$ \\
Rusia & 45 & $10.8 \%$ \\
Perancis & 30 & $7.2 \%$ \\
Turki & 20 & $4.8 \%$ \\
Spanyol & 9 & $2.2 \%$ \\
Kroasia & 4 & $1.0 \%$ \\
Jerman & 2 & $0.5 \%$ \\
Portugis & 2 & $0.5 \%$ \\
Bulgaria & 1 & $0.2 \%$ \\
Italia & 1 & $0.2 \%$ \\
Persia & 1 & $0.2 \%$ \\
Polandia & 1 & $0.2 \%$ \\
\hline
\end{tabular}

\section{Area Subjek}

Penelitian selanjutnya mengklasifikasikan berdasarkan bidang area subjek seperti yang terdapat pada Tabel 7, penelitian mengenai Muslim Travel muncul terutama dari Ilmu Sosial 90 (21,6\%), Seni dan Humaniora 75 (18,0\%), Bisnis Manajemen dan Akuntansi 40 (9,6\%) dan urutan terendah Dokter Hewan 1 (0,2\%).

Tabel 7. Area Subjek

\begin{tabular}{lcc}
\hline Area Subjek & $\begin{array}{c}\text { Jumlah Artikel yang di } \\
\text { Publikasikan }\end{array}$ & \%(N=416) \\
\hline Ilmu Sosial & 90 & $21.6 \%$ \\
Seni dan Humaniora & 75 & $18.0 \%$ \\
Obat-obatan & 55 & $13.2 \%$ \\
Bisnis, Manajemen dan Akuntansi & 40 & $9.6 \%$ \\
Ilmu Lingkungan & 32 & $7.7 \%$ \\
Teknik & 25 & $6.0 \%$ \\
Ekonomi, Ekonometrika dan Keuangan & 20 & $4.8 \%$ \\
Ilmu Komputer & 18 & $4.3 \%$ \\
Psikologi & 15 & $3.6 \%$ \\
Ilmu Bumi dan Planet & 9 & $2.2 \%$ \\
Imunologi dan Mikrobiologi & 7 & $1.7 \%$ \\
\hline
\end{tabular}




\begin{tabular}{lll}
\hline Ilmu Keputusan & 5 & $1.2 \%$ \\
Ilmu Pertanian dan Biologi & 4 & $1.0 \%$ \\
Energi & 4 & $1.0 \%$ \\
Profesi Kesehatan & 3 & $0.7 \%$ \\
Biokimia, Genetika dan Biologi Molekular & 3 & $0.7 \%$ \\
Matematika & 3 & $0.7 \%$ \\
Ilmu Material & 2 & $0.5 \%$ \\
Farmakologi, Toksikologi dan Farmasi & 2 & $0.5 \%$ \\
Ilmu Saraf & 1 & $0.2 \%$ \\
Keperawatan & 1 & $0.2 \%$ \\
Fisika dan Astronomi & 1 & $0.2 \%$ \\
Dokter Hewan & 1 & $0.2 \%$ \\
\hline
\end{tabular}

\section{Lembaga Aktif}

Peneliti juga menganalisis Lembaga aktif teratas yang berkontribusi dalam topik Muslim Travel, Sebagian besar penelitian berasal dari Ministry of Health Saudi Arabia, Arab Saudi, diikuti oleh University of Malaya, Malaysia, King Saud University, Arab Saudi, Columbia University, Amerika Serikat, King Abdulaziz University, Arab Saudi, International Islamic University Malaysia, dan King Saud University Medical College.

Tabel 8. Lembaga aktif

\begin{tabular}{lll}
\hline Lembaga & Frekuensi & $\mathbf{\% ( N = 4 1 6 )}$ \\
\hline Ministry of Health Saudi Arabia & 20 & $4.8 \%$ \\
University of Malaya & 12 & $2.9 \%$ \\
King Saud University & 11 & $2.6 \%$ \\
Columbia University & 8 & $1.9 \%$ \\
King Abdulaziz University & 7 & $1.7 \%$ \\
International Islamic University Malaysia & 6 & $1.4 \%$ \\
King Saud University Medical College & 6 & $1.4 \%$ \\
Alfaisal University & 6 & $1.4 \%$ \\
Health Protection Agency & 5 & $1.2 \%$ \\
Universiti Kebangsaan Malaysia & 5 & $1.2 \%$ \\
The Australian National University & 5 & $1.2 \%$ \\
Universiti Putra Malaysia & 5 & $1.2 \%$ \\
\hline
\end{tabular}




\section{Konseptual Struktur}

\section{Jaringan Kejadian Kata Kunci}

Pada gambar 3 ditampilkan jaringan kejadian yang terdapat pada topik Muslim Travel, pada jaringan kejadian terdapat plot merah dan plot biru, plot merah meliputi node article, humans, islam, travel, religion, muslim, human, Saudi arabia, islamicsm dan plot biru meliputi node middle aged, adult, male, female, priority journal, aged. Antara node yang terdapat pada plot merah dan plot biru saling berhubungan.

Tabel 9 menampilkan 19 node teratas seperti travel dengan cluster (1) betweenness $(0,912257383)$, saudi arabia cluster (1) betweenness (0), human cluster (1) betweenness (1.02125377), Female cluster (2) betweenness (0.853866547), Male cluster (2) betweenness (0.565046376).

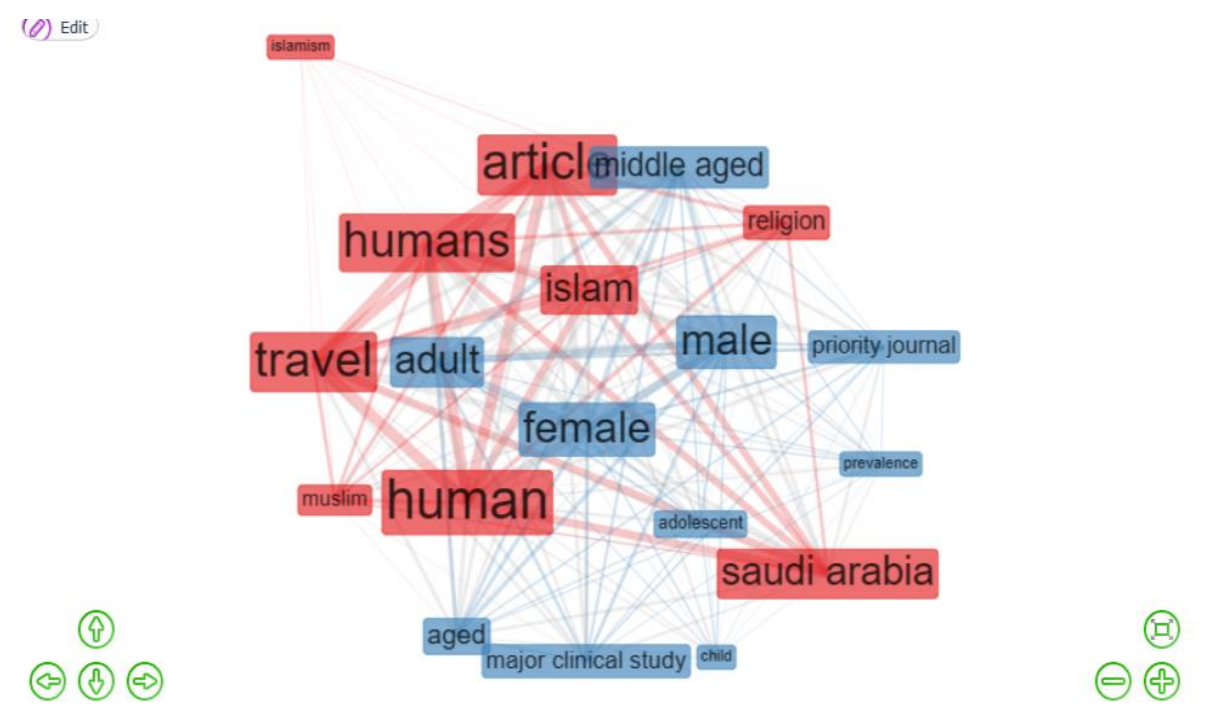

Gambar 3. Jaringan Kejadian Kata Kunci 
Tabel 9. Jaringan Kejadian Kata Kunci

\begin{tabular}{lllll}
\hline Node & Cluster & Betweenness & Closeness & PageRank \\
\hline travel & 1 & 0.912257383 & 0.055555556 & 0.081158294 \\
saudi arabia & 1 & 0 & 0.052631579 & 0.062720622 \\
human & 1 & 1.02125377 & 0.055555556 & 0.090732297 \\
Islam & 1 & 0.409216793 & 0.055555556 & 0.061734199 \\
article & 1 & 0.973672195 & 0.055555556 & 0.08277402 \\
humans & 1 & 0.557144644 & 0.055555556 & 0.078706024 \\
religion & 1 & 0.660833737 & 0.055555556 & 0.037824985 \\
islamism & 1 & 0 & 0.04 & 0.011114084 \\
muslim & 1 & 0.148207895 & 0.055555556 & 0.03367339 \\
female & 2 & 0.853866547 & 0.055555556 & 0.071809593 \\
Male & 2 & 0.565046376 & 0.055555556 & 0.071267852 \\
Adult & 2 & 0.505339194 & 0.055555556 & 0.065476978 \\
Aged & 2 & 0 & 0.052631579 & 0.043839797 \\
middle aged & 2 & 0.393161466 & 0.055555556 & 0.051920365 \\
adolescent & 2 & 0 & 0.052631579 & 0.03023159 \\
priority journal & 2 & 0 & 0.052631579 & 0.036923457 \\
Child & 2 & 0 & 0.052631579 & 0.023002661 \\
major clinical & 2 & & 0.052631579 & 0.039534899 \\
study & 2 & 0 & 0.052631579 & 0.025554894 \\
prevalence & & 0 & & \\
\hline
\end{tabular}

\section{Thematic Maps}

Pada penelitian selanjutnya peneliti membahas Thematic Maps berdasarkan topik Muslim Travel, dapat dilihat pada gambar 4 bahwa kata kunci yang paling banyak muncul dari topik Muslim Travel adalah Human, diikuti dengan Female, Islamicsm dan Prevalence.

Pada tabel 10 peneliti mengambil 10 teratas kata kunci yang berhubungan dengan topik Muslim Travel. Travel dengan Occurrences (84), Saudi Arabia (63), Human (99), Islam (59), Article (86), Public Health (15) dan Vaccination (15). 


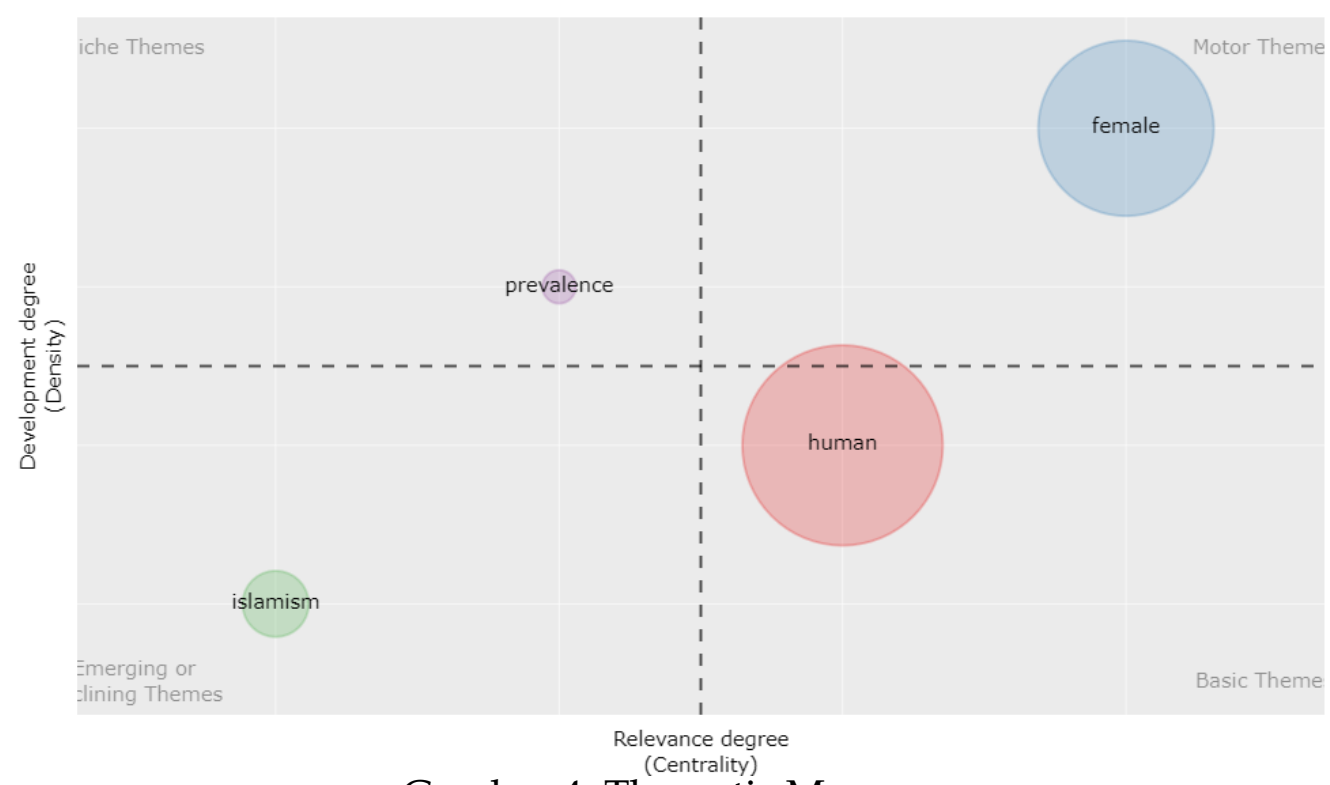

Gambar 4. Thematic Maps

Tabel 10. Thematic Maps

\begin{tabular}{llll}
\hline Occurrences & Words & Cluster & Cluster_Label \\
\hline 84 & travel & 1 & human \\
63 & saudi arabia & 1 & human \\
99 & human & 1 & human \\
59 & islam & 1 & human \\
86 & article & 1 & human \\
78 & humans & 1 & human \\
43 & religion & 1 & human \\
30 & muslim & 1 & human \\
15 & public health & 1 & human \\
15 & vaccination & 1 & human \\
\hline
\end{tabular}

\section{Intelektual Struktur}

\section{Jaringan Kutipan}

Pada gambar 5 peneliti membahas mengenai jaringan kutipan penulis yang berhubungan dengan Muslim Travel, terdapat 2 plot biru dan merah. Plot Biru terdiri 
dari cohen, zamanifarahani, battour, hair, Rahman, kim dan lee. Plot Merah terdiri dari khan, ahmed, rashid, memish dan gautret.

Pada tabel 11 peneliti mengambil 15 teratas penulis yang berhubungan dengan topik Muslim Travel. Memish dengan betweenness (0.87219806), Closeness (0.047619048), diikuti dengan khan betweenness (6.798789058), Closeness (0.071428571).

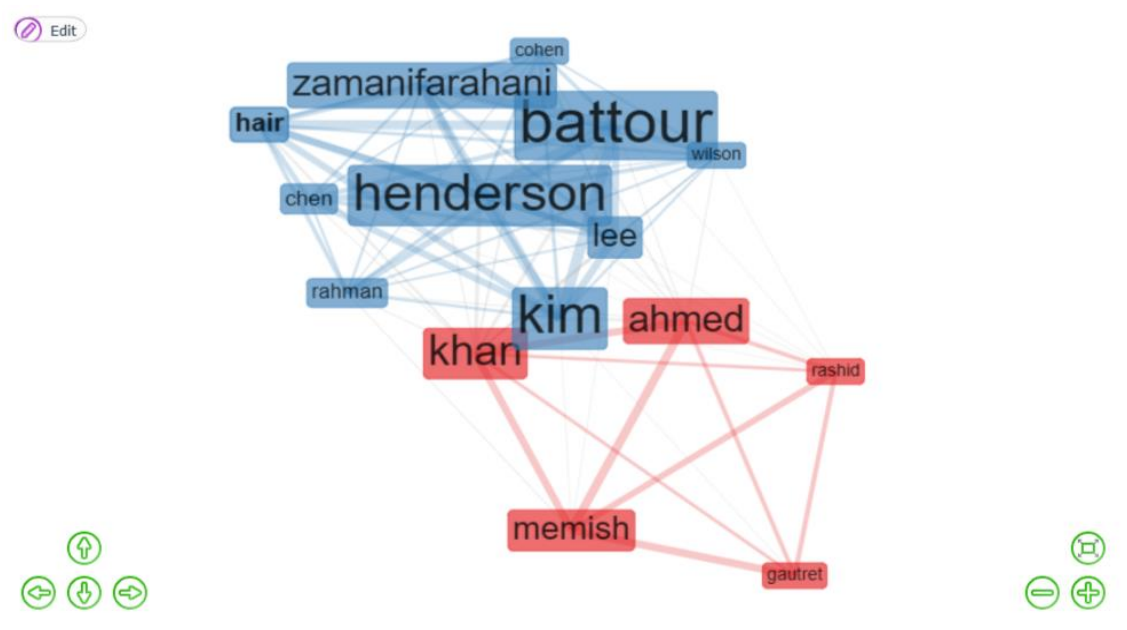

Gambar 5. Jaringan Kutipan

Tabel 11. Jaringan Kutipan

\begin{tabular}{lllll}
\hline Node & Cluster & Betweenness & Closeness & PageRank \\
\hline memish & 1 & 0.87219806 & 0.047619048 & 0.060607341 \\
khan & 1 & 6.798789058 & 0.071428571 & 0.073927377 \\
ahmed & 1 & 4.486465122 & 0.066666667 & 0.066200242 \\
gautret & 1 & 0 & 0.043478261 & 0.042033656 \\
rashid & 1 & 0.913242408 & 0.052631579 & 0.044779028 \\
battour & 2 & 1.072738333 & 0.0625 & 0.108592965 \\
kim & 2 & 4.425764796 & 0.071428571 & 0.096043495 \\
henderson & 2 & 0.839903281 & 0.0625 & 0.097026065 \\
rahman & 2 & 0.772639102 & 0.0625 & 0.051284008 \\
wilson & 2 & 0.310455393 & 0.0625 & 0.046410797 \\
lee & 2 & 1.307296833 & 0.066666667 & 0.071835976 \\
cohen & 2 & 0.063451777 & 0.058823529 & 0.045657422 \\
hair & 2 & 0 & 0.055555556 & 0.066326286 \\
chen & 2 & 0.045685279 & 0.058823529 & 0.056963364 \\
zamanifarahani & 2 & 0.091370558 & 0.058823529 & 0.072311978 \\
\hline
\end{tabular}




\section{Sosial Struktur}

\section{Kolaborasi Jaringan Penulis}

Pada gambar 6 peneliti mengambil 15 penulis teratas ditandai dengan plot-plot warna, terdapat 9 warna. Penulis tersebut terdiri dari Memish za, Ahmed qa, Khan a, Yezli s, Assiri a, Rashid h, Booy r, Paula p, Gautret p, Musa g, Al-ansi a, Han h, Alhomoud f.

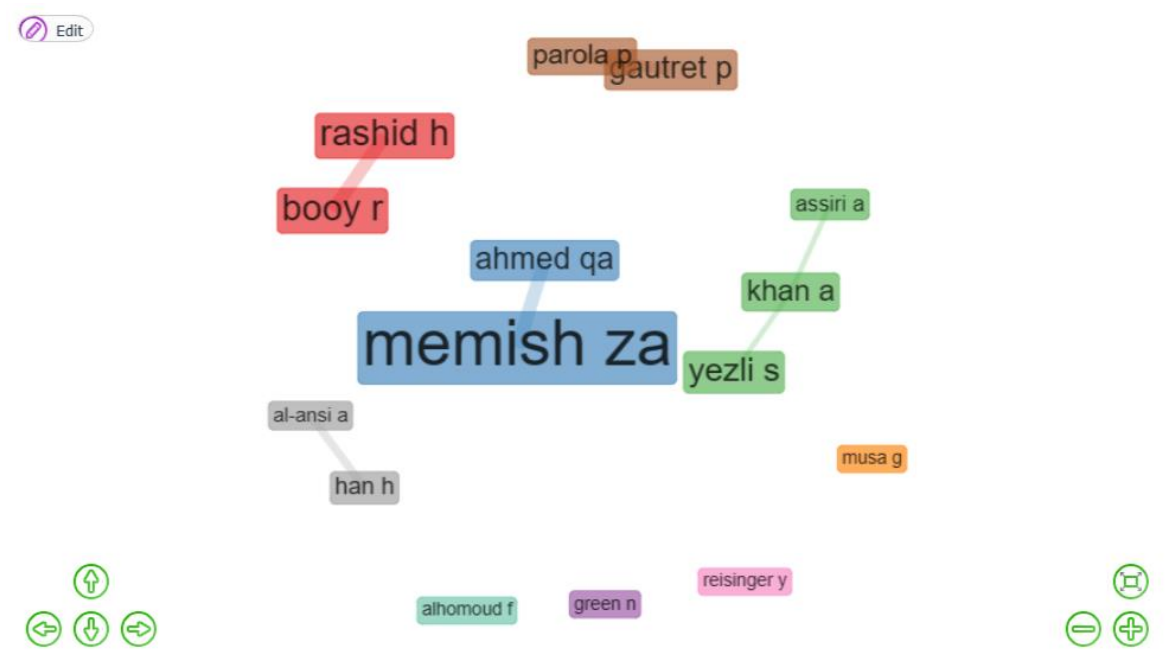

Gambar 6. Kolaborasi Jaringan Penulis

Dan pada tabel 12 menampilkan cluster, betweenness, closeness dan page rank dari masing masing 15 penulis teratas, cluster tertinggi ditempati oleh alhompound $\mathrm{f}(9)$ dengan betweenness (0), closeness (0.004761905) dan page rank (0.012931034) diikuti dengan al-ansi a (8) dengan betweenness (0), closeness $(0.005102041)$ dan page rank (0.086206897) dan cluster terendah ditempati oleh booy $r$ dengan (1) cluster, betweenness (0), closeness (0.005102041) dan page rank (0.086206897). 
Tabel 12. Kolaborasi Jaringan Penulis

\begin{tabular}{lllll}
\hline Node & Cluster & Betweenness & Closeness & PageRank \\
\hline booy $\mathrm{r}$ & 1 & 0 & 0.005102041 & 0.086206897 \\
rashid $\mathrm{h}$ & 1 & 0 & 0.005102041 & 0.086206897 \\
memish za & 2 & 0 & 0.005102041 & 0.086206897 \\
ahmed qa & 2 & 0 & 0.005102041 & 0.086206897 \\
khan a & 3 & 1 & 0.005494505 & 0.125815471 \\
yezli s & 3 & 0 & 0.005464481 & 0.06640261 \\
assiri a & 3 & 0 & 0.005464481 & 0.06640261 \\
green $\mathrm{n}$ & 4 & 0 & 0.004761905 & 0.012931034 \\
musa g & 5 & 0 & 0.004761905 & 0.012931034 \\
gautret $\mathrm{p}$ & 6 & 0 & 0.005102041 & 0.086206897 \\
parola $\mathrm{p}$ & 6 & 0 & 0.005102041 & 0.086206897 \\
reisinger y & 7 & 0 & 0.004761905 & 0.012931034 \\
han h & 8 & 0 & 0.005102041 & 0.086206897 \\
al-ansi a & 8 & 0 & 0.005102041 & 0.086206897 \\
alhomoud f & 9 & 0 & 0.004761905 & 0.012931034 \\
\hline
\end{tabular}

\section{Kolaborasi Peta Dunia}

Penelitian selanjutnya peneliti membahas mengenai kolaborasi peta dunia, dapat dilihat pada tabel 13 terdapat negara-negara yang berkontribusi dalam topik Muslim Travel. Frekuensi negara tertinggi ditempati dari negara Indonesia ke Australia dengan (6) frekuensi diikuti oleh negara Australia ke China dengan (2) frekuensi dan frekuensi terendah di tempati oleh negara Australia ke Finland dengan (1) Frekuensi.

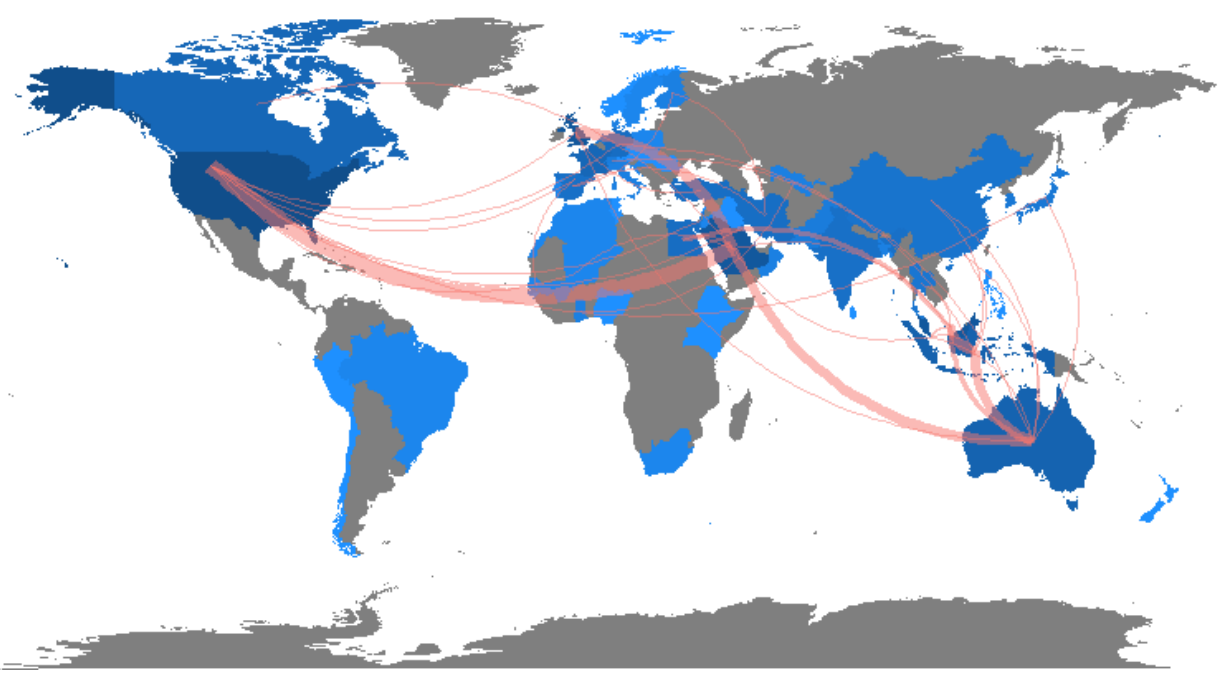


Tabel 13. Kolaborasi Peta Dunia

\begin{tabular}{lll}
\hline From & To & Frequency \\
\hline INDONESIA & AUSTRALIA & 6 \\
AUSTRALIA & CHINA & 2 \\
AUSTRALIA & GERMANY & 2 \\
AUSTRALIA & HONG KONG & 2 \\
AUSTRALIA & JAPAN & 2 \\
AUSTRALIA & SINGAPORE & 2 \\
FRANCE & SENEGAL & 2 \\
GHANA & UZBEKISTAN & 2 \\
INDONESIA & CHINA & 2 \\
AUSTRALIA & FINLAND & 1 \\
\hline
\end{tabular}

\section{Kesimpulan}

Berdasarkan hasil penelitian diatas penelitian ini memuat tinjauan terhadap dua jenis karya ilmiah yang telah di terbitkan mengenai Muslim Travel, pada penelitian ini menjelaskan mengenai penelitian sebelumnya dengan menggunakan Bibliometrik dengan data yang didapatkan melalui database scopus. Di dapatkan sebanyak 416 dokumen, karya ilmiah muncul sejak tahun 1963 yang dimana mengalami penurunan dan kenaikan sampai dengan tahun 2021.

Semua artikel dan conference paper dominan di terbitlkan dalam bahasa inggris, dan memiliki penulis tunggal hingga multi penulis, peneliti juga mendapati bahwa topik Muslim Travel pada kolaborasi negara-negara masih sangatlah banyak, peneliti juga mendapatkan bahwa banyak universitas di berbagai negara yang ikut berpartisipasi dalam topik Muslim Travel. Akan tetapi meskipun scopus merupakan database online yang paling luas dalam mengindeks karya ilmiah tetapi tidak sepenuhnya mencakup semua data sumber yang tersedia karena tidak ada kata kunci penelusuran yang benar - benar sempurna. 


\section{Daftar Pustaka}

Arifiyyati, May Firdaw. 2020. "Wisata Halal Trend Baru Industri Pariwisata Korea Selatan." Jurnal Penelitian 14(1):153.

Ayatina, H., F. T. Astuti, and M. miqdam Makfi. 2020. “Tren Bisnis \& Penerapan Prinsip Syariah Pada Industri Perhotelan Pariwisata Halal Di Indonesia." AtThullab Jurnal Mahasiswa Studi Islam 2:506-18.

Hayati, Nurul, and Lolytasari Lolytasari. 2017. "Produktivitas Dosen Uin Syarif Hidayatullah Jakarta Pada Jurnal Terindeks Scopus: Suatu Kajian Bibliometrik." Al-Maktabah 16(1):22-31.

Herdianto, Roni, Nia Windyaningrum, Betty Masruroh, and Mohamad Arief Setiawan. 2021. "Filsafat Pendidikan Dan Perkembangannya: Kajian Bibliometrik Berdasarkan Database Scopus." Belantika Pendidikan 4(1):44-56.

Kusumaningtyas, Menur, Fitri Nur Latifah, Miya Dewi Suprihandari, and Muhammad Syauqi. 2021. "Pariwisata Ramah Halal Di Negara Non Muslim: Studi Observasi Di Nepal (Halal Friendly Tourism in Non-Muslim Countries: Observational Study in Nepal)." PERISAI: Islamic Banking and Finance Journal 5(April):51-63.

Prasetyo, Hendi. 2021. “Analisis Bibliometrik Pada Scholarly Journals Proquest Dengan Kata Kunci 'Tourism In Indonesia' Menggunakan Perangkat Lunak Vosviewer." Khasanah Ilmu: Jurnal Pariwisata Dan Budaya 12(1):16-21.

Rusydiana, Muhammad, Pratomo, Endang, Sanrego. 2021. "Halal Tourism Indicators: A Bibliometric Study." Library Philosophy and Practice.

Samori, Zakiah, Nor Zafir Md Salleh, and Mohammad Mahyuddin Khalid. 2016. "Current Trends on Halal Tourism: Cases on Selected Asian Countries." Tourism Management Perspectives 19(June 2020):131-36.

Shofi'unnafi, S. 2020. "Muslim Milenial Sebagai Katalisator Industri Pariwisata Halal Indonesia: Mencari Titik Temu Potensi Dan Atensi." Jurnal Ilmiah Syi'ar 20(1):89.

Sidiq, Muhaemin. 2019. "Panduan Analisis Bibliometrik Sederhana." Journal Article (June).

Tupan, Tupan, Rochani Nani Rahayu, Rulina Rachmawati, and Endang Sri Rusmiyati Rahayu. 2018. "Analisis Bibliometrik Perkembangan Penelitian Bidang Ilmu Instrumentasi." Baca: Jurnal Dokumentasi Dan Informasi 39(2):135. 


\section{Profil Penulis}

Mochammad Givary Ramadhan, adalah Mahasiswa Program Studi Perbankan Syariah Fakultas Agama Islam, Universitas Muhammadiyah Sidoarjo Angkatan 2018.

M. Ruslianor Maika, S.Hut. MAB, menyelesaikan strata satu di Universitas Winaya Mukti Program Studi Kehutanan. Strata duanya ditempuh di Sekolah Bisnis dan Manajemen ITB dalam Program Studi Islamic Banking and Finance. Saat ini penulis adalah dosen di Universitas Muhammadiyah Sidoarjo. 